\title{
Kemampuan Pemecahan Masalah Dan Disposisi Matematis Pada Materi Kubus Dan Balok Ditinjau Dari Kemampuan Matematika
}

\author{
Uswatun Hasanah', Aprilia Dwi Handayani², Dian Devita Yohanie ${ }^{3}$ \\ uswatun.alhasanah@gmail.com¹; apriliadwi@unpkediri.ac.id2; diandevita@unpkediri.ac.id³ \\ Program Studi Pendidikan Matematika1,2,3 \\ Universitas Nusantara PGRI Kediri1,2,3
}

\begin{abstract}
This research is motivated by the importance of problem-solving abilities and mathematical dispositions on cube and block material in terms of mathematical abilities. Where the objectives of learning mathematics contain cognitive aspects seen from problem-solving abilities and affective aspects which can be seen from mathematical dispositions. The purpose of this study was to describe problem solving abilities and mathematical dispositions, as well as the relationship between the two in the cube and block material in terms of mathematical abilities. This research was conducted at SMP Pawyatan Daha 2 Kediri City with the research subjects of class IX. The approach used is a qualitative approach. Data were collected by giving test questions of problem-solving abilities, giving mathematical disposition questionnaires, and interviews based on the results of test questions by each subject. The conclusions of the results of this study are (1) The problem-solving ability of students is generally in quite good criteria (2 Students' mathematical disposition is generally in good criteria, and (3) There is no significant relationship between problem-solving abilities and mathematical dispositions.
\end{abstract}

Keywords: Problem solving skill; Cubes and Blocks; Mathematical Disposition, mathematical skills

\begin{abstract}
Abstrak
Penelitian ini dilatarbelakangi pentingnya kemampuan pemecahan masalah dan disposisi matematis pada materi kubus dan balok yang ditinjau dari kemampuan matematika. Dimana tujuan dari pembelajaran matematika memuat aspek kognitif yang dilihat dari kemampuan pemecahan masalah dan aspek afektif dapat dilihat dari disposisi matematis. Penelitian ini bertujuan untuk mendeskripsikan kemampuan pemecahan masalah dan disposisi matematis, serta keterkaitan antara keduanya untuk materi kubus dan balok ditinjau dari aspek kemampuan matematika. Tempat pelaksanaan dalam penelitian ini di SMP Pawyatan Daha 2 Kota Kediri dengan subjek penelitian kelas IX. Adapun Pendekatan yang digunakan dalam penelitian ini memakai pendekatan kualitatif. Pengambilan data dilaksanakan dengan langkah memberikan soal tes kemampuan pemecahan masalah, memberikan angket disposisi matematis, dan melakukan wawancara berdasarkan hasil dari soal tes kemampuan pemecahan masalah oleh masing-masing subjek. Kesimpulan dari hasil penelitian ini adalah (1) Kemampuan pemecahan masalah siswa secara umum berada pada kriteria cukup baik (2 Disposisi matematis siswa secara umum berada pada kriteria baik, dan (3) Tidak terdapat keterkaitan secara signifikan antara kemampuan pemecahan masalah dan disposisi matematis.
\end{abstract}

Kata Kunci: kemampuan pemecahan masalah, disposisi matematis, kubus dan balok, kemampuan matematika

\section{PENDAHULUAN}

Mempelajari matematika dalam kehidupan sangat penting karena matematika mendorong perkembangan manusia dari berbagai aspek. Oleh karena itu untuk menghadapi perkembangan 
tersebut dimasa depan maka diperlukan kemampuan matematika baik dari segi kognitif tentang pengetahuan dan pemahaman maupun dari segi afektif yang berkaitan tentang sikap. Menurut NCTM (2000) kemampuan matematika adalah keahlian mendasar yang diperlukan dalam menguasai matematika berupa memahami konsep dan informasi prosedural yang bisa diterapkan untuk mengatasi setiap problematika dalam belajar matematika.

Kemampuan pemecahan masalah dalam penguasaan matematika mencakup kemampuan ranah kognitif dasar yang utama dan harus dimiliki pada siswa. Hal ini dikarenakan, siswa akan memperoleh pengalaman mengaplikasikan konsep mereka untuk digunakan dalam proses mengerjaan soal dan memecahkan masalah matematika sehingga siswa lebih terampil dalam mengambil tindakan yang tepat.

Urgensi kemampuan pemecahan masalah pada proses pembelajaran matematika dipaparkan National Council of Teacher of Mathematics (NCTM). NCTM (2000) menyatakan bahwa proses berpikir siswa terdiri dari lima kompetensi utama yang akan dilewati saat belajar matematika yaitu keahlian memecahkan masalah, menalar, mengaitkan konsep satu dengan yang lainnya, kemampuan mengkomunikasikan gagasan, dan kemampuan representasi. Menurut Saad \& Ghani (2008: 120), pemecahan masalah adalah serangkaian proses untuk mendapatkkan hasil dengan sepenuhnya agar tercapai tujuan supaya memperoleh jawaban atas masalah yang memperlukan sebuah strategi yang telah disusun sebelumnya. Siswa perlu melakukan beberapa tahapan dalam memecahkan masaah seperti menerima masalah yang dihadapi, merencanakan sebuah desain ide penyelesaian masalah, melaksanakan ide yang diambil, dan menyelidiki untuk memastikan hasil yang didapatkan.

Pemecahan masalah matematis mendorong siswa berpikir kritis, inovatif, dan mengeksplor keahlian matematis lainnya. Salah satu cara pemecahan masalah adalah menggunakan langkah polya. Menurut aturan Polya (1973:5), alur pemecahan masalah meliputi empat fase sebagai berikut:

\section{Fase memahami masalah}

Fase awal pada proses penyelesaian masalah yaitu memahami inti masalah. Pertama Siswa harus mengetahui terlebih dahulu tentang informasi yang sudah diketahui dan informasi apa saja yang belum dapat diakses, serta informasi apa saja yang perlu dicari.

2. Fase merencanakan pemecahan

Siswa mencari dan memilih beberapa strategi yang akan diperlukan untuk menyelesaikan masalah di antaranya seperti: mencoba ide, mensketsa ide dengan membuat diagram, menyederhanakan soal, menemukan keteraturan pola, menyusun tabel, percobaan, memeriksa semua rencana, dan menggabungan semua informasi.

\section{Fase melaksanakan rencana}

Setelah menemukan rencana pemecahan yang tepat, fase berikutnya adalah menerjemahkan data yang diperoleh ke bahasa numerik dan menerapkan strategi selama rangkaian pengerjakan soal. Siswa perlu mempertahankan strategi yang sudah diambil. Siswa dapat memilih rencana lain sebagai alternatif untuk menyelesaikan masalah apabila rencana tersebut tidak bisa terlaksana.

\section{Fase Memeriksa kembali}

Ketika meriksa kembali penting memperhatikan cara yang telah digunakan saat menyelesaikan masalah, yaitu: meriksa ulang data penting yang telah teridentifikasi, meriksa data yang melibatkan prses berhitung, meninjau solusi yang tepat, melihat alternatif solusi yang lain, dan memastikan semua soal sudah dijawab dengan tepat. 
Berdasarkan kurikulum 2013 (kemendikbud:24) dipaparkan tujuan pembelajaran adalah menghasilkan siswa indonesia yang produktif, kreatif, inovatif serta afektif dengan adanya penguatan sikap, keterampilan, dan pengetahuan yang saling menyatu. Dalam pelaksanaan soft skill dan hard skill matematis harus dijalankan beriringan dan seimbang sesuai pedoman kurikulum matematika. Apabila dikaitkan dengan tujuan pembelajaran matematika, maka hal tersebut telah sesuai, karena yang mencakup sasaran-sasaran dalam berbagai ranah kognitif dan afektif meliputi: memiliki sikap keingintahuan, memiliki antusias dalam belajar matematika, tekun, dan tekad yang kuat untuk menuntaskan masalah, serta menghargai manfaat ilmu matematika di kehidupan. Ketika pembelajaran matematika berlanjut akan tercipta kecenderungan berpikir dan bertindah positif terhadap matematika yang disebut disposisi matematis (Hendriana, Rohaeti, Sumarmo:130).

Sumarmo (2012:3) mengungkapkan bahwa disposisi matematis adalah kemauan siswa sendiri untuk tetap mempelajari matematika dengan tekun, dan mengerjakan beraneka tantangan matematika. Wardani (2009:15) menambahkan bahwa disposisi matematis merupakan aspresiasi dan kecenderungan mengaplikasikan matematika melalui berpikir, beraktifitas positif, percaya diri, keingintahuan, antusias, tekun belajar, fleksibel, serta merefleksi dalam aktivitas matematis.

Menurut NCTM (1991) ada beberapa indikator disposisi matematis mencakup sebagai berikut: (1) menerapkan ilmu matematika dengan percayaan diri, memecahkan masalah yang dihadapi, mengutarakan alasan dan mengkomunikasikan gagasan matematis; (2) memecahkan masalah matematis dengan cara menyelidiki gagasan matematis dengan fleksibel dan berusaha menemukan strategi alternatif; (3) mengerjakan kegiatan matematis dengan tekun; (4) menunjukkan ketertarikan, keingintahuan, dan daya cipta dalam mengerjakan kegiatan matematis; (5) meninjau hasil keputusan dan penalaran; (6) menggunakan matematika ke berbagai situasi; dan (7) mengapresiasi karya matematika dalam kebudayaan sebagai alat dan bahasa. Mencermati uraian tersebut, indikator penelitian ini meliputi: (1) kepercayaan diri; (2) fleksibilitas; (3) kegigihan; (4) rasa keingintahuan; (5) reflektif; (6) aplikasi matematika; dan (7) apresiasi matematika.

\section{METODE PENELITIAN}

Penelitian ini menggunakan metode jenis pendekatan kualitatif deskriptif. Pelaksanaan penelitian di kelas IX SMP Pawyatan Daha 2 Kota Kediri pada bulan Desember 2020. Pemilihan subjek diambil berdasarkan kategori kemampuan tinggi, sedang, dan rendah dari hasil soal tes. Subjek diambil enam siswa dari dua siswa pada kategori kemampuan tinggi, dua siswa pada kategori kemampuan sedang, dan dua siswa pada kategori kemampuan rendah.

Metode pengumpulan data yang digunakan meliputi: tes kemampuan pemecahan masalah, angket disposisi matematis, dan wawancara. Instrumen dalam penelitian ini adalah silabus, kisi-kisi soal tes, kisi-kisi angket disposisi matematis, kisi-kisi wawancara, lembar soal tes, lembar rubrik soal tes, lembar rubrik penskoran pemecahan masalah kemampuan matematika, lembar angket disposisi matematis, dan lembar pedoman wawancara. Jenis tes berupa uraian yang digunakan untuk melihat kemampuan pemecahan masalah matematis siswa dan sebagai bahan pedoman wawancara. Angket yang digunakan berjenis kuesioner tertutup deng skala likert lima poin yang bertujuan guna mengetahui kriteria kemampuan disposisi matematis siswa. Wawancara disini berbentuk tidak terstruktur digunakan untuk mengetahui lebih mendalam bagaimana proses siswa dalam mengerjakan soal tes sehingga dapat dipakai untuk mendukung jawaban tes siswa terhadap kemampuan pemecahan masalah. 
Untuk selanjutnya data yang terkumpul akan dianalisa hingga mendapatkan kriteria sangat baik, baik, cukup baik, kurang baik, dan sangat kurang baik. Teknik analisa data yang digunakan adalah model alur yang dikemukakan oleh Miles \& Suberman (Gunawan, 2013:210) sebagai berikut ini:

1. Tahap reduksi data

Tahap pertama dalam mereduksi data penelitian meliputi : (1) Mengoreksi hasil pengerjaan soal tes siswa, dan (2) mengoreksi hasil angket siswa.

2. Tahap penyajian data

Tahap kedua daalm menyajikan data meliputi: (1) menyajikan data pengerjaan soal tes siswa guna dibuat pedoman wawancara, (2) menyajikan data rekaman dari kegiatan wawancara yang telah dilakukan.

3. Tahap penarikan kesimpulan dan memverifikasi data

Data yang telah dianalisa akan dilakukan penarikan kesimpulan. Selanjutnya dilakukan teknik pengecekan keabsahan data menggunakan triangulasi untuk mempertanggungjawabkan kebenaran data.

\section{HASIL DAN PEMBAHASAN}

Pada penelitian ini mengambil subyek dengan tiga kategori yaitu kemampuan tinggi, sedang, dan rendah. Didapatkan enam subjek penelitian yang disajikan dalam tabel di bawah ini:

Tabel 1. Subjek Penelitian

\begin{tabular}{llll}
\hline No. & Nama Inisial & Nama Lengkap & Kategori \\
\hline 1. & AN & Arini Novita Sari & Tinggi \\
2. & MR & Mochammad Revaldo Putra & Tinggi \\
3. & NR & Nasya Rihadatul 'Aisy & Sedang \\
4. & FN & Fery Noval Mahendra & Sedang \\
5. & MA & Mayang Arum Lestari & Rendah \\
6. & RO & Rizky Oktavian Putra Pratama & Rendah \\
\hline
\end{tabular}

Berdasarkan analisa data penelitian yang dikumpulkan selama pelaksanaan pekerjaan lapangan. Analisa data terdiri dua bagian yaitu analisa pemecahan masalah matematis siswa dan analisa disposisi matematis.

1. Hasil kemampuan pemecahan masalah matematis pada materi kubus dan balok

Kriteria kemampuan pemecahan masalah menurut Arikunto (2010:245) disajikan pada tabel 2 di bawah ini :

Tabel 2. Kriteria Kemampuan Pemecahan Masalah

\begin{tabular}{ll}
\hline Nilai & Kriteria \\
\hline $80-100$ & Sangat Baik \\
$66-79$ & Baik \\
$56-65$ & Cukup Baik \\
$40-55$ & Kurang Baik \\
$0-39$ & Sangat Kurang Baik \\
\hline
\end{tabular}


Efektor, Volume 8 Issue 2, 2021, Pages 110 - 121

Uswatun Hasanah, Aprilia Dwi Handayani, Dian Devita Yohanie

Hasil Kemampuan pemecahan masalah siswa pada materi kubus dan balok yang ditinjau dari pengerjaan soal tes dan wawancara akan ditriangulasi yang disajikan dalam tabel 3 berikut:

Tabel 3. Triangulasi Data Hasil Wawancara dan Tes

\begin{tabular}{lllll}
\hline Subjek & \multicolumn{2}{c}{ Pengambilan Data } & Nilai Rata- & Kriteria \\
\cline { 2 - 4 } Penelitian & Tes & Wawancara & rata & \\
\hline AN & 78,2 & 87,3 & 82,75 & Sangat Baik \\
MR & 89,1 & 87,3 & 88,2 & Sangat Baik \\
NR & 56,4 & 78,2 & 67,3 & Baik \\
FN & 43,7 & 63,6 & 53,65 & Cukup Baik \\
MA & 27,3 & 49 & 38,15 & Kurang Baik \\
RO & 25,5 & 41,8 & 33,65 & Sangat Kurang Baik \\
\hline
\end{tabular}

Dari data triangulasi tes dan wawancara yang telah dirangkum dalam tabel diatas, setiap subjek akan dideskripsikan sebagai berikut:

a. Subjek AN

Kemampuan pemecahan masalah subjek AN berada pada kriteria sangat baik. Subjek AN mampu merencanakan dan melaksanakan pemecahan masalah dilihat dengan penggunakan rumus yang tepat dan hasil perhitungan benar. Subjek AN juga memeriksa hasil jawaban akhir. Namun pada tahap memahami soal, subjek AN tidak menuliskan unsur yang diketahui. Saat wawancara subjek AN mampu menjelaskan apa yang sudah dikerjakan dengan lancar.

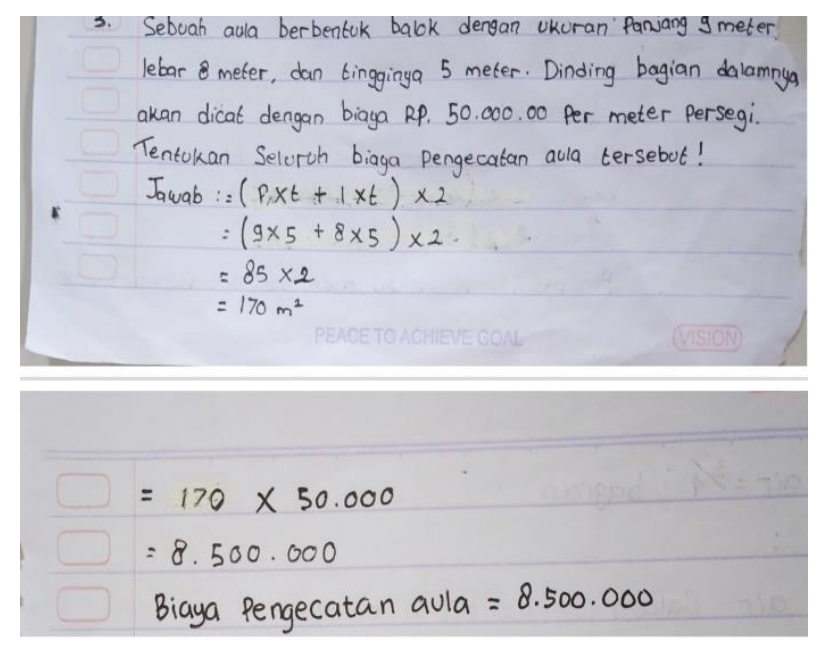

Gambar 1. Hasil Pekerjaan Subjek AN 
b. Subjek MR

Kemampuan pemecahan masalah subjek MR menempati di kriteria sangat baik. Subjek MR mampu memahami masalah dengan menuliskan informasi yang diketahui di soal dan mampu merencanakan pemecahan masalah dengan mencari informasi lain yang diperlukan. Subjek MR juga berhasil menyelesaian masalah dengan menuliskan cara yang tepat dan memeriksa jawaban akhir. Saat wawancara subjek MR mampu menjelaskan apa yang sudah dikerjakan dengan lancar dan penuh percaya diri.

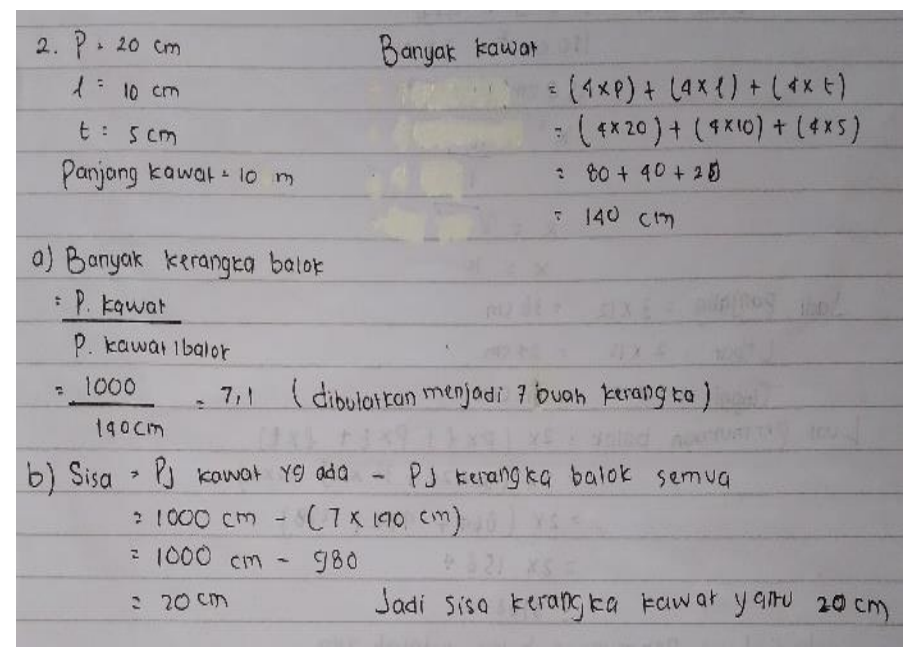

Gambar 2. Hasil Pekerjaan Subjek MR

c. Subjek NR

Kemampuan pemecahan masalah subjek NR menempati kriteria baik. Subjek NR mampu memahami masalah dengan menuliskan informasi yang diketahui dan menyetarakan dalam satuan lain. Pada tahap merencanakan subjek MR menuliskan rumus dengan tepat. Saat melaksanakan pemecahan masalah juga tidak terjadi kesalahan, namun satuan tidak dituliskan dalam satuan meter atau sentimeter. Serta subjek NR tidak memeriksa hasil jawaban akhir. Saat wawancara subjek NR mampu menjelaskan apa yang sudah dikerjakan.

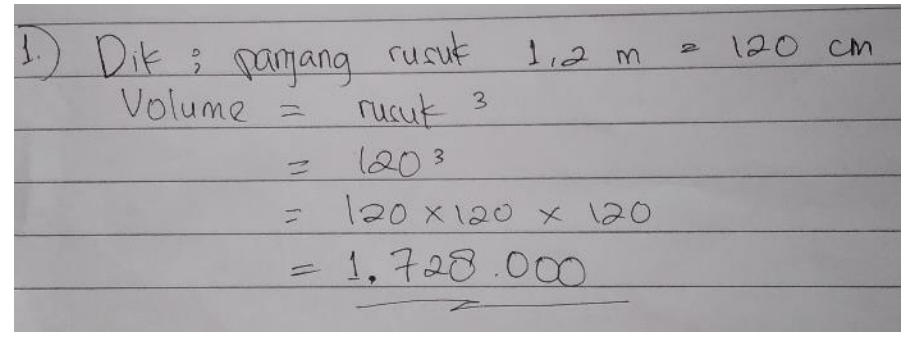

Gambar 3. Hasil Pekerjaan Subjek NR

d. Subjek FN

Kemampuan pemecahan masalah subjek FN berada pada kriteria cukup baik. Subjek FN mampu memahami dan merencanakan masalah. Namun subjek FN ada kesalahan ditahap melaksanakan pemecahan masalah yaitu salah dalam mensubsitusi angka ke rumus, sehingga dalam perhitungan juga menghasilkan jawaban yang tidak tepat. Saat wawancara subjek FN kurang mampu menjelaskan apa yang sudah dikerjakan. 
Efektor, Volume 8 Issue 2, 2021, Pages 110 - 121

Uswatun Hasanah, Aprilia Dwi Handayani, Dian Devita Yohanie

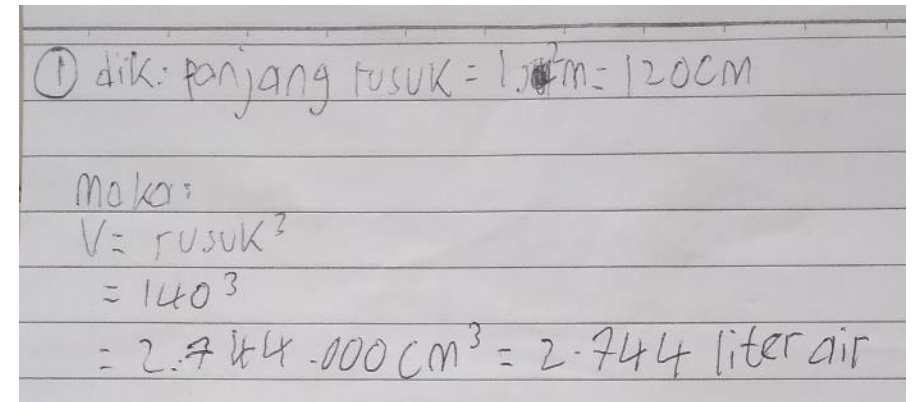

Gambar 4. Hasil Pekerjaan Subjek FN

e. Subjek MA

Kemampuan pemecahan masalah subjek MA berada pada kriteria kurang baik. Subjek MA hanya mampu menjawab satu soal benar. Subjek MA tidak menuliskan rumus dan tidak menggunakan rumus dengan benar, serta tidak memeriksa apa yang dikerjakan. Sehingga subjek MA pada tahap merencanakan dan melaksanakan tidak memenuhi indikator. Saat wawancara subjek MA kurang mampu menjelaskan apa yang sudah dikerjakan.

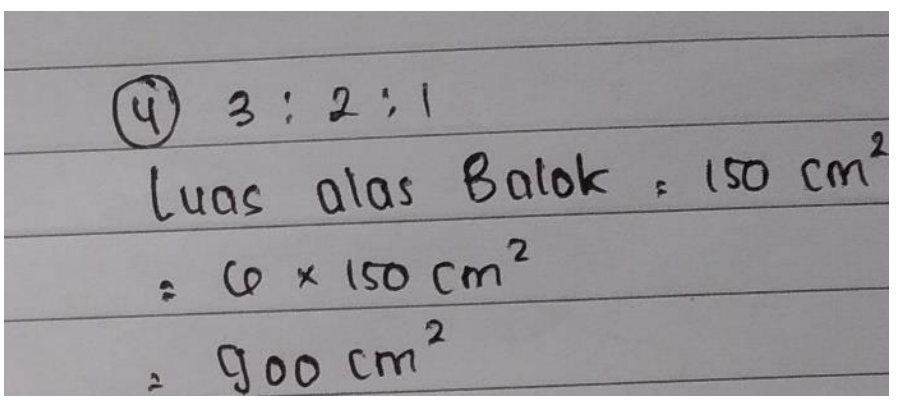

Gambar 5. Hasil Pekerjaan Subjek MA

f. Subjek RO

Kemampuan pemecahan masalah subjek RO berada pada kriteria sangat kurang baik. Subjek RO tidak mampu memahami, merencanakan, melaksanakan, dan memeriksa semua soal. Subjek RO tidak mengerti rumus yang seharusnya digunakan. Saat wawancara subjek RO tidak mampu menjelaskan informasi yang sudah dikerjakan.

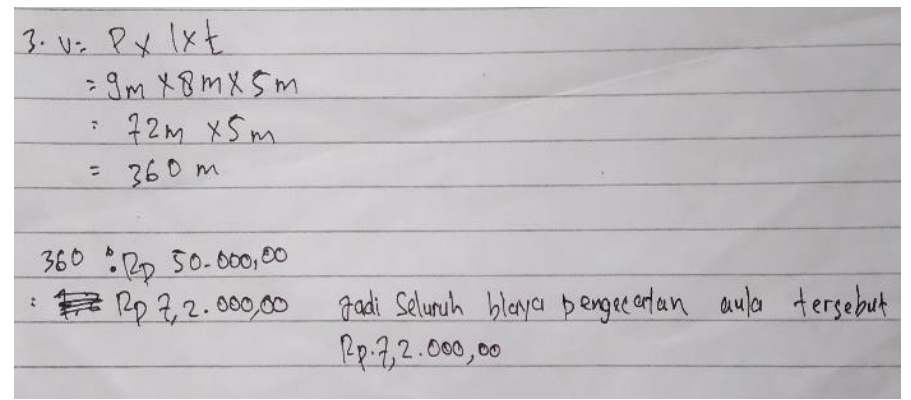

Gambar 6. Hasil Pekerjaan Subjek RO 
Efektor, Volume 8 Issue 2, 2021, Pages 110 - 121

Uswatun Hasanah, Aprilia Dwi Handayani, Dian Devita Yohanie

2. Disposisi matematis pada materi kubus dan balok

Kriteria interpretasi skor disposisi matematis menurut Riduwan (2015 : 89) sebagai berikut :

Tabel 4. Kriteria Disposisi Matematis

\begin{tabular}{ll}
\hline Skor & Kriteria \\
\hline $80-100$ & Sangat Baik \\
$66-79$ & Baik \\
$56-65$ & Cukup Baik \\
$40-55$ & Kurang Baik \\
$0-39$ & Sangat Kurang Baik \\
\hline
\end{tabular}

Hasil disposisi matematis pada materi kubus dan balok pada siswa dengan kemampuan matematika pada kategori tinggi berada di kriteria sangat baik dan sangat baik. Sedangkan pada siswa dengan kemampuan matematika pada kategori sedang, disposisi matematis berada pada kriteria baik dan cukup baik. Dan pada siswa dengan kemampuan matematika pada kategori rendah berada pada kriteria baik dan baik. Hasil disposisi matematis disajikan dalam tabel 5 berikut:

Tabel 5. Data Hasil Disposisi Matematis

\begin{tabular}{lll}
\hline $\begin{array}{l}\text { Subjek } \\
\text { Penelitian }\end{array}$ & Nilai & Kriteria \\
\hline AN & 81,6 & Sangat Baik \\
MR & 94,4 & Sangat Baik \\
NR & 78,4 & Baik \\
FN & 59,2 & Cukup Baik \\
MA & 72 & Baik \\
RO & 68 & Baik \\
\hline
\end{tabular}

Dari hasil angket yang telah dirangkum dalam tabel, setiap subjek akan dideskripsikan sebagai berikut:

\section{a. Subjek AN}

Disposisi matematis subjek AN berada pada kriteria baik. Subjek AN memiliki fleksibilitas, kegigihan, rasa keingintahuan, relektif, aplikasi, dan apresiasi matematika yang baik. Namun memiliki kepercayaan diri yang kurang dalam mengkomunikasikan ide-ide matematis nya dan tidak berani bertanya kepada guru apabila menemukan materi yang tidak paham. 
b. Subjek MR

Disposisi matematis subjek MR berada pada kriteria sangat baik. Subjek MR memiliki fleksibilitas, kegigihan, relektif, aplikasi, dan apresiasi matematika yang baik. Serta subjek MR memiliki kepercayaan diri dalam menyelesaikan masalah matematika yang sangat baik dan mampu mengkomunikasikan gagasan dengan lancar. Subjek MR juga memiliki rasa keingintahuan yang sangat baik dengan sering bertanya kepada guru atau teman, dan mengeksplor ide-ide matematis.

c. Subjek NR

Disposisi matematis subjek NR berada pada kriteria baik. Subjek NR memiliki kepercayaan diri, rasa keingintahuan, relektif, aplikasi, dan apresiasi matematika yang baik. Namun memiliki fleksibilitas yang kurang dalam bekerjasama saat belajar matematika bersama teman. Subjek NR juga memiliki kegigihan yang kurang karena belajar matematika saat ada ulangan atau tugas saja.

d. Subjek FN

Disposisi matematis subjek FN berada pada kriteria cukup baik. Subjek FN memiliki kegigihan, aplikasi, dan apresiasi matematika yang baik. Namun memiliki fleksibilitas yang kurang dalam mencoba berbagai metode alternatif untuk menyelesaikan masalah. Subjek FN memiliki kepercayaan diri yang kurang dalam mengkomunikasikan ide-ide matematisnya. Subjek FN juga memiliki sikap reflektif yang kurang dalam merefleksikan atau menyimpulkan apa yang telah dipelajari sebelumnya.

e. Subjek MA

Disposisi matematis subjek MA berada pada kriteria baik. Subjek MA memiliki kepercayaan diri, flelsibilitas, relektif, aplikasi, dan apresiasi matematika yang baik. Namun memiliki rasa kegigihan yang kurang dalam belajar matematika. Subjek MA juga memiliki rasa keingintahuan yang kurang dalam mengeksplor ide-ide matematis.

f. Subjek RO

Disposisi matematis subjek RO berada pada kriteria baik. Subjek RO memiliki, flelsibilitas, kegigihan, rasa keingintahuan, aplikasi, dan apresiasi matematika yang baik. Namun memiliki kepercayaan diri yang kurang dalam bertanya kepada guru apabila menemukan kendala dalam memahami materi. Subjek RO juga memiliki sikap reflektif yang kurang dalam mengulang materi sebelumnya dan malas dalam memeriksa hasil jawaban.

3. Keterkaitan kemampuan pemecahan masalah matematika dengan disposisi matematis pada materi kubus dan balok ditinjau dari kemampuan matematika

Hasil keterkaitan kemampuan pemecahan masalah matematika dengan disposisi matematis pada materi kubus dan balok disajikan dalam grafik berikut: 
Efektor, Volume 8 Issue 2, 2021, Pages 110 - 121

Uswatun Hasanah, Aprilia Dwi Handayani, Dian Devita Yohanie

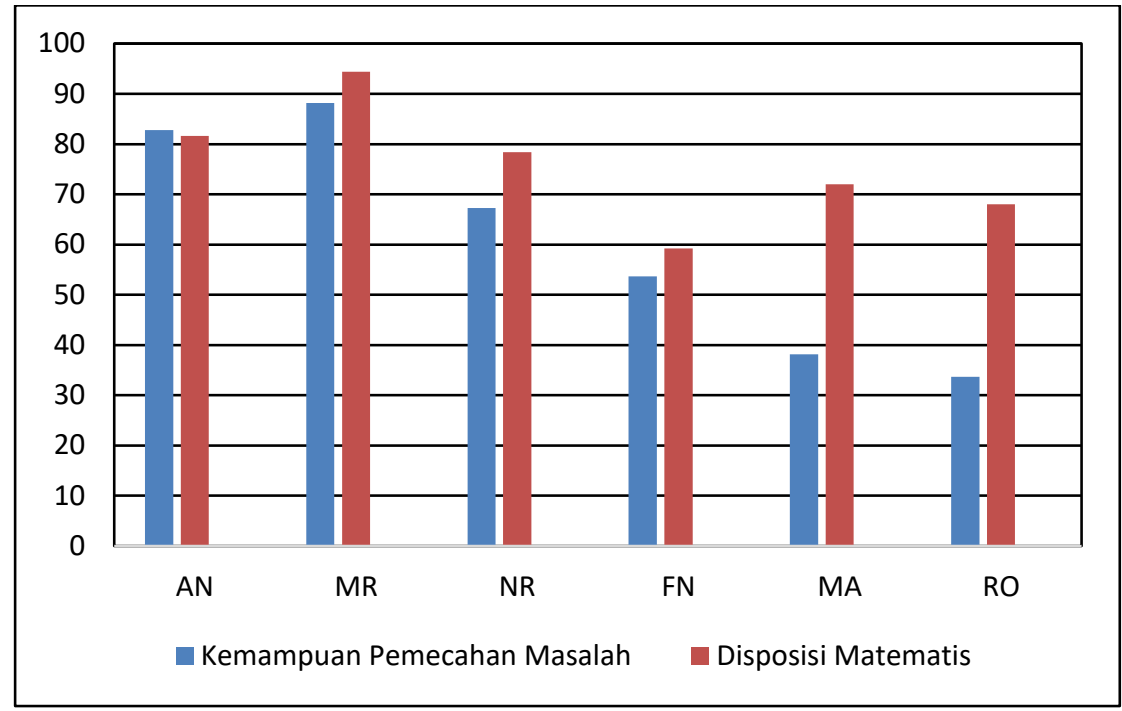

Grafik 1. Keterkaitan antara Kemampuan Pemecahan Masalah dan Disposisi Matematis

Dari grafik 1. Diperoleh hasil bahwa siswa dengan tingkat kemampuan pemecahan masalah yang sangat baik memiliki disposisi matematis yang sangat baik. Namun siswa dengan kemampuan pemecahan masalah menunjukkan kurang baik belum pasti memiliki disposisi matematis yang kurang baik pula.

Diperkuat dengan ungkapan Mahmudi (2010 : 9) bahwa disposisi matematis dapat menunjang kemampuan matematika, termasuk salah satunya kemampuan pemecahan masalah. Apabila siswa mempunyai disposisi matematis yang tinggi, maka saat melakukan pekerjaan akan lebih tekun dan giat pada proses memecahkan masalah, serta terbentuk kebiasaan positif dalam pembelajaran matematika. Hal ini dapat memotivasi siswa mempunyai kemampuan yang lebih daripada siswa yang tidak memperlihatkan kecondongan disposisi matematis. Meski demikian, disposisi matematis bukan termasuk persyaratan absolut untuk menumbuhkan kemampuan pemecahan masalah. Sehingga meskipun memiliki disposisi matematis baik tidak menjamin kemampuan pemecahan masalah nya menunjukkan hasil yang baik pula.

\section{SIMPULAN}

Berdasarkan hasil analisa data dan pembahasan, diperoleh kesimpulan bahwa kemampuan pemecahan masalah pada materi kubus dan balok untuk siswa kategori tinggi memiliki kemampuan pemecahan masalah dalam kriteria sangat baik. Siswa kategori sedang memiliki kemampuan pemecahan masalah dalam kriteria baik atau cukup baik. Siswa kategori rendah memiliki kemampuan pemecahan masalah dalam kriteria kurang baik atau sangat kurang baik. Oleh karena itu dapat ambil kesimpulan bahwa kemampuan pemecahan masalah matematis siswa secara umum menunjukkan kriteria "Cukup Baik".

Disposisi matematis untuk siswa kategori tinggi memiliki disposisi matematis dengan kriteria sangat baik. Siswa kategori sedang memiliki disposisi matematis dengan berada antara baik dan cukup baik. Siswa kategori rendah memiliki disposisi matematis dengan kriteria baik. Sehingga disimpulkan yaitu disposisi matematis secara umum berada pada kriteria "Baik". 
Keterkaitan antara kemampuan pemecahan masalah matematis dengan disposisi matematis pada materi kubus dan balok yaitu antara keduanya tidak terdapat keterkaitan yang signifikan. Terbukti dari hasil didapatkan bahwa siswa dengan tingkat kemampuan pemecahan masalah menunjukkan kurang baik belum pasti memiliki disposisi matematis yang kurang baik. Tetapi ada kecenderungan bahwa siswa yang memiliki kemampuan pemecahan yang sangat baik akan memiliki disposisi matematis yang sangat baik.

Berdasarkan penelitian yang telah dilaksanakan, maka peneliti merekomendasikan kepada peneliti lain yang akan melaksanakan penelitian, sebaiknya melakukan observasi lapangan dengan teliti karena pemilihan subjek yang tepat sasaran akan menentukan hasil penelitian yang tepat pula.

\section{DAFTAR RUJUKAN}

Arikunto, Suharsimi. (2010). Dasar-Dasar Evaluasi Pendidikan (Edisi Revisi). Jakarta: Bumi Aksara.

Gunawan, Imam. (2015). Metode Penelitian Kualitatif Teori dan Praktek. Jakarta: Bumi Aksara.

Hendriana, H., Rohaeti, E.E., \& Sumarmo, U. (2017). Hard Skills dan Soft Skill Matematik Siswa. Bandung: Refika Aditama.

Kemendikbud. (2014). Konsep dan Implementasi Kurikulum 2013. https://www.kemdikbud.go.id/kemdikbud/dokumen/Paparan/Paparan\%20Wamendik.pdf. Diakses Januari 2021.

Mahmudi, Ali. (2010). Tinjauan Asosiasi antara Kemampuan Pemecahan Masalah Matematis dan Disposisi Matematis. Makalah disajikan pada seminar nasional pendidikan matematika FMIPA Universitas Negeri Yogyakarta : Yogyakarta, 17 April 2010.

NCTM (National Council of Teachers of Mathematics). (1991). Professional Standards for Teaching Mathematics. Evaluation of Teaching: Standard 6: promoting Mathematical Disposition. Reston, VA: Author.

NCTM (National Council of Teachers of Mathematics). (2000). Principles and Standards for School Mathematics. Reston, VA: Author.

Polya. G. (1973). How to Solve It: A New Aspect of Mathematichal Method (Seconded). New Jersey: Princeton University Press.

Riduwan. (2015) Belajar Mudah Penelitian untuk Guru-Karyawan dan Peneliti Pemula. Bandung : Alfabeta.

Saad, N.S. \& Ghani, A.S. (2008). Teaching mathematics in Secondary Scholl Theories and Practices. Perak : Universiti Pendidikan Sultran Idris.

Sugiono. (2015). Metode Penelitian Kuantitatif, Kualitatif, dan R\&D. Bandung: Alfabeta.

Sumarmo, Utari., Hidayat, W., Zulkarnaen, R., Hamidah, Sariningsih, R. (2012). Kemampuan dan Disposisi Berpikir Logis, Kritis, dan Kreatif Matematik (Eksperimen terhadap Siswa SMA 
Efektor, Volume 8 Issue 2, 2021, Pages 110 - 121

Uswatun Hasanah, Aprilia Dwi Handayani, Dian Devita Yohanie

Menggunakan Pembelajaran Berbasis Masalah dan Strategi Think-Talk-Write). Bandung: Jurnal FMIPA UPI.

Wardani, S. (2009). Meningkatkan Kemampuan Berpikir Kreatif dan Disposisi Matematik Siswa SMA Melalui Pembelajaran dengan Pendekatan Model Sylver. Bandung: Disertasi Program Pascasarjana UPI. 